Chapman University

Chapman University Digital Commons

Political Science Faculty Articles and Research

Political Science

2012

\title{
Political Theory in Institutional Context: The Case of Patriot Royalism
}

John Compton

Chapman University, compton@chapman.edu

Karen Orren

University of California - Los Angeles

Follow this and additional works at: http://digitalcommons.chapman.edu/polisci_articles

Part of the Christian Denominations and Sects Commons, Christianity Commons, Constitutional Law Commons, History of Christianity Commons, and the Religious Thought, Theology and Philosophy of Religion Commons

\section{Recommended Citation}

Compton, John, and Karen Orren. "Political Theory in Institutional Context: The Case of Patriot Royalism." American Political Thought $3.1(2014): 1-31$.

This Article is brought to you for free and open access by the Political Science at Chapman University Digital Commons. It has been accepted for inclusion in Political Science Faculty Articles and Research by an authorized administrator of Chapman University Digital Commons. For more

information, please contact laughtin@chapman.edu. 


\section{Political Theory in Institutional Context: The Case of Patriot Royalism}

Comments

This article was originally published in American Political Thought, volume 3, issue 1, in 2014.

\section{Copyright}

University of Chicago Press 


\title{
Political Theory in Institutional Context: The Case of Patriot Royalism
}

\author{
JOHN W. COMPTON and KAREN ORREN
}

\begin{abstract}
In the aftermath of the Stamp Act, prominent American thinkers of otherwise unquestioned Whiggish affiliation adopted an expansive view of the king's prerogative powers while simultaneously denying Parliament's authority to interfere in the internal governance of the colonies. Scholars have generally attributed this stance, known as "patriot royalism," to political necessity: with no other means of disputing Parliament's oppressive actions, desperate pamphleteers sought to revive the discredited constitutional ideas of the Stuarts. In contrast, we argue that this position was deeply rooted in the institutional context of colonial governance. More specifically, we show that revolutionary Americans directly experienced lawmaking by Privy Council and the Board of Trade over which, as a practical matter, there was no higher authority. This "conciliar" form of governance, which survived the break with England, exerted a significant influence on the constitutional framers and their handiwork.
\end{abstract}

Americans are accustomed to reading words of the United States Constitution in light of their precise historical setting. Indeed, it would be considered the height of foolishness to attempt to discern the meaning of, say, "equal protection" without reference to the social and institutional context in which the phrase is used. If anything, the British constitution, lacking a single or express text, requires even greater caution. No phrases have figured more importantly in English (or American) political history than lex terram and per judicium parium suorum in Magna Carta. But no one would dream of

John W. Compton is assistant professor in the Department of Political Science, Chapman University (compton@chapman.edu). Karen Orren is professor in the Department of Political Science, UCLA (orren@ucla.edu).

The authors would like to thank Joyce Appleby, Eric Nelson, Peter Onuf, Stephen Skowronek, and the anonymous reviewers and editor of American Political Thought for their helpful comments and criticisms.

American Political Thought: A Journal of Ideas, Institutions, and Culture, vol. 3 (Spring 2014).

2161-1580/2014/0301-0004\$10.00. @ 2014 by The Jack Miller Center. All rights reserved. 
arguing that their operations were the same within the institutions of the thirteenth century as they were even four or five hundred years later, to say nothing of eight. Similarly problematic are the contemporaneous ideas proffered by legal commentators and political philosophers. Valuable for so many reasons, their viewpoint is at best one step removed from the acts and dispositions of the institutions about which they write.

Surely there could be no precepts less controversial. Yet there is at least one prominent episode of American history in which scholars at the top level of distinction have, in the presence of a conundrum of their own making, thrown this unimpeachable wisdom to the winds. We speak about the "curious" if undeniable royalist strand in early American political thought. During the imperial crisis of the 1760s and early 1770s, American writers of upstanding Whig ideology denied Parliament's authority to legislate for the colonies in favor of an (allegedly) antiquated defense of the king's prerogative, redolent of arguments made by James I. Interpretations of this anomaly have stopped short of calling these colonists themselves ignorant, but that charge in essence has been leveled against historians who have credited the argument as more than an exit strategy from an otherwise inescapable corner. Thus, Charles McIlwain, whose book The American Revolution: A Constitutional Interpretation was published as long ago as 1924, was chided in print for disinterring "the bones of that ancient controversy that was settled by force in America some 150 years ago" (McIlwain 1924; Goebel 1930, 273). ${ }^{1}$

That the bones have remained above ground is highlighted by a recent symposium in the William and Mary Quarterly, the centerpiece article of which, written by Eric Nelson, rechristens the colonists' position "patriot royalism" (Nelson 2011). ${ }^{2}$ Nelson joins several distinguished historians who have revisited the controversy and lent a measure of plausibility to what they see as a genuine change of heart, albeit one undertaken opportunistically and under severe duress. In both his and John Phillip Reid's telling, for instance, these colonists followed the only logic left to them after more ideologically favored routes were closed down, one that led inexorably to the seventeenth century. ${ }^{3}$ Likewise, Jack Greene, Barbara Black, and others have expounded on what patriot writers found in the reign of the Stuarts, which was a balanced constitution, based on the principles of government by consent and the legally bind-

1. For a more extensive critique of McIlwain's arguments, see Schuyler (1924).

2. For the responses to Nelson's essay, see Hulsebosch (2011), Maier (2011), and Wood (2011).

3. More specifically, Nelson argues that patriot writers embraced the royal prerogative only after attempts to define the precise limits of Parliamentary authority were met with “cogent objections" that proved unanswerable (2011, 536). Also see Marston (1987, 36-39), and Reid (1993, 140-41, 152, 156-57). 
ing force of custom (Black 1976; Greene 1986, 144-50). ${ }^{4}$ It was on that basis, all agree, that the colonists embraced the royal prerogative and called on George III to reassert it against Parliament. Nelson arguably goes somewhat farther than the others to (briefly) suggest that the old monarchical forms, once rehabilitated, bore fruit in the plans of nation builders like Alexander Hamilton (Nelson 2011, 572).

Our essay has no quarrel with the idea that important constitutional precepts can be found secreted in the rule of the Stuarts, nor with the sense of impending catastrophe that must have intensified their meaning for North Americans in the mid-eighteenth century. Where we differ is in our crediting "patriot royalism" not to the colonists' rediscovery of Stuart governance but to lived experience of their own. Against the background of the prerogative's exercise through the Privy Council and the Board of Trade for well over a century, it seemed in no sense far-fetched to appeal to the same authority when more ideologically favored institutions took on a sinister cast. Nor, as we see it, does this institutional dimension simply add another complexity in an already complicated historical narrative. For where the other scholars mentioned have seen discontinuity and more or less desperate invention-Nelson's word is "rupture" -we observe continuity, the colonists' building on what was familiar (Nelson 2011, 537). Going further, we argue that only the institutional grounding of patriot royalism explains the persistence in postrevolutionary American governments of "conciliar" forms directly associated with monarchy, and not as residues but by design. ${ }^{5}$ We see no reductionism in any of this, only the formative influence of the stage upon which political actors' motives and strategies take shape.

The emphasis on institutions as foundational to the colonists' thinking also distinguishes our stance on the pivotal question of sovereignty during the period. Others have remarked on the plurality of authorities on all sides and the inherent instability of any definition of sovereignty that might contend with the clear-cut notion the Whigs embraced on Parliament's behalf. ${ }^{6}$ Again, we

4. One point of disagreement within this literature concerns the underlying motivation of patriots who appealed to the prerogative. Black argues that "the [patriot] desire for sole external authority in the king ... resulted from the perception that" the relative weakness of royal institutions would soon leave the North American colonies under "no external authority . . . whatsoever" $(1976,1193)$. By contrast, Nelson argues that such appeals were, at least by the early 1770 s, motivated by a sincere hope that the king would use the royal negative to oppose parliamentary regulation of colonial affairs (2011, 536-37).

5 . In this respect, our article builds on several recent works that identify important continuities between pre- and postrevolutionary modes of governance. See, e.g., Hulsebosch (2005), Bilder (2008), LaCroix (2010).

6. See, e.g., Bailyn (1967, 216-29) and Greene (2011, 202-3). Bailyn writes that "the concept of [parliamentary] sovereignty was not only logical but realistic" in England but 
are agreeably aligned on the matter of perceptions. But we adopt an empirical disposition as to the actual operations of authority as they bore on the colonies; for that reason we will undertake to review details not captured in overall generalizations about multiplicity. Taking as our standard of sovereignty the right to make new law within a given sphere, we are interested in how this right was shared between conciliar and representative agencies. This definition comports not only with understandings that extend beyond nominal designations today, but with the difference between "making" and "finding" law during the eighteenth century. This also allows us to catch the sovereignty-in-transition that will transfer into both the political institutions and the political thought of the young republic as the separation of powers (see Orren 1994). This may appear to beg the question, since it was the issue of which institution had the authority to rightfully make laws for the colonies that exploded with the Stamp Act. Our concern, however, is with practices-largely uncontested-before that time.

In 1766, Benjamin Franklin took up his pen to answer members of the House of Lords who had recently voted against the successful repeal of the Stamp Act. Working off a printed copy of the Lords' arguments, by now widely distributed in the colonies, Franklin covered its margins with what was virtually a line-by-line rebuttal, apparently intending to publish his handiwork as a pamphlet. Franklin's audacious claim was that the Lords lacked an adequate understanding of the English constitution. Particularly misguided-and irritating-was their description of Parliament as "sovereign" legislative power in the empire. While he was perfectly willing to submit to the "sovereignty of the Crown," he could "not understand" what might be meant by the "sovereignty of the British legislature outside of Britain." Parliament's power to tax extended "to all the members of the state," to be sure, but the Lords seemed to have forgotten that the North American colonies were not annexed to the realm, that they were in fact "separate States, Subject to the King" (Franklin $1959,13: 220,215)^{7}$

was "far from that in the colonies. Indeed, "from the beginning of settlement, circumstances in America had run directly counter to the exercise of unlimited and undivided sovereignty."

7. Although the precise date of Franklin's marginal notes, which were never published in pamphlet form, is not known, the editor of the Franklin papers series concludes that they were "probably" written shortly after the Lords' protest was published (Franklin 1959, 13:207-9). A nearly identical description of the colonies' relationship to the home country, written only a few months after the publication of the dissenting Lords' protest, can be found in a February 1767 letter from Franklin to Lord Kames: "All the Colonies acknowledge the 
The timing of Franklin's broadside is important, for it locates a fully articulated "patriot royalism" very near the start of Parliament's aggressive stance toward the colonies. This fact contrasts with Nelson's view that it was "in the wake of the Townshend Acts" that one may observe the "beginning" of the patriots' "jettisoning their previous insistence that Parliament was sovereign over the colonies, but simply lacked authority to legislate for them in particular respects" (Nelson 2011, 534-35). For Bernard Bailyn, as well, Franklin's key arguments, gathered together in what came to be known as the "dominion theory," would not become significant until the 1770s, after a period of failed attempts to delineate a workable limit to Parliament's authority (Bailyn 1967, 104-43). ${ }^{8}$ But the readiness-the instinctiveness, as it were-of Franklin's response so soon after the disturbing events at issue argues for it being a reflection of how governance operated in North America at that time and not a product of anguished historical research.

Franklin's writings on the Stamp Act are sometimes dismissed as the idiosyncratic musings of a man who was, after all, on the crown's payroll and who harbored dreams of a career in the royal bureaucracy. ${ }^{9}$ Yet even a cursory review of pamphlets published in 1765 and 1766 reveals that he was neither the first nor the only one to conceptualize the American colonies as "separate states, subject to the King." In May, for example, a "Plain Yeoman"-he may well have been Rhode Island's popularly elected governor, Stephen Hopkins-took to the pages of the Providence Gazette to deny that the North American colonies were in any way dependent upon the British people or their representatives in Parliament: "I know of no dependence or relation, only that we are all subjects of the same king. . . . I cannot find that the inhabitants of the colonies are dependent on the people of Britain, or the

King as their Sovereign. . . . Laws are made by their Assemblies or little Parliaments . . . subject . . . to the King's Pleasure to confirm or annul them. Suits arising in the Colonies, and Differences between Colony and Colony, are not brought before your Lords of Parliament . . . but determined by the King in Council. In this View they seem so many separate little States, subject to the same Prince. The Sovereignty of the King is therefore easily understood. But . . . the [idea of the] Sovereignty of Parliament, and the Sovereignty of this Nation over the Colonies ... is not so clear, nor does it clearly appear on what Foundations it is established" (Franklin 1959, 14:62-71, 68; emphasis in the original). Franklin was more circumspect in his 1766 testimony before a committee of the House of Commons, yet still went so far as to describe the colonies as "not . . within the realm" and possessed of "assemblies of their own, which are their parliaments" (Morgan 1959, 143-46, 145).

8. The "dominion theory" of empire is discussed at length in McIlwain (1924, 114-47). For additional statements of the view that the patriots arrived at this position gradually, after attempting and failing to delineate a workable limit to Parliament's authority over colonial affairs, see Wood $(1969,344-54)$, and Greene $(2011,92)$.

9. On the relationship between Franklin's constitutional views and his professional background and ambitions, see Wright (1986, 172-83), and Wood (2004, 105-51). 
people of Britain on them, any more than Kent is on Sussex, or Sussex on Kent." Nor could the Stamp Act's opponents be accused of "aiming at independence," since, the writer insisted, the thought of "shak[ing] off . . . allegiance to the crown" had never "entered into our breasts" ("A Letter from a Plain Yeoman"; Morgan 1959, 73). ${ }^{10}$ A few months later, a "Britannus Americanus" expressed nearly identical sentiments in the Boston Gazette: "the people of England could have no more political connection . . . or power and jurisdiction over [the colonists], than they now have with or over the people of Hanover, who are also subjects of the same king" ("Britannus Americanus"; Hyneman and Lutz 1983, 1:89-91). And another anonymous writer in the Pennsylvania Gazette declared at the height of the Stamp Act crisis that the empire was in effect a "confederacy of states, independent of each other, yet united under one head," with "all the powers of legislation . . f full and compleat in each part" (F.L., "The Objection to American Representation in Parliament"; Morgan 1959, 91). Or, for a final example, an anonymous New York pamphleteer, also writing in 1765, averred that the king "was the sovereign of America, distinct from the power and authority of parliament," and that Parliament therefore lacked the constitutional authority to "lay any tax . . . whatsoever within this your dominion of America" (C.P. 1765, 1). ${ }^{11}$

No question, such assertions were more common in the early 1770 s than in the mid-1760s. Some patriot pamphlets of the Stamp Act period are (like

10. Emphasis in the original. It should be pointed out that a 1764 pamphlet ("The Rights of the Colonies Examined") drafted by Hopkins declares it the "duty" of "good and loyal" Americans to "obey and patiently submit" to acts of Parliament that pertain to the colonies' external affairs. Even here, however, Hopkins describes the empire as consisting of "many separate governments each of which hath peculiar privileges," with "no single part . . . entitled to make laws for" another part. "Indeed," he wrote, "it would be absurd to suppose that the common people [of] Great Britain have a sovereign and absolute authority over their fellow subjects in America, or even any sort of power whatsoever over them" (Hyneman and Lutz 1983, 1:45-61, 58).

11. It is also worth noting that the resolutions of protest drafted by the Sons of Liberty and similar groups frequently contained expressions of dismay, not only at Parliament's interference with the rights of the colonists, but at Parliament's trampling upon "his majesty's just prerogative" (Morgan 1959, 116, 117). Moreover, even pamphleteers who viewed the royal prerogative as a threat to the colonists' liberties tended to accept that this power rested on firmer constitutional footing than the related claims of Parliament. The anonymous 1766 pamphleteer "Aequus," after denying Parliament's authority to legislate for the colonies, acknowledged that it was "with more justice [asserted] that the King's Scepter is the instrument of power over the colonies, and Prerogative the rule by which their obedience must be regulated" (Hyneman and Lutz 1983, 1:62-66, 64). Another 1766 pamphleteer, likely William Hicks, declared that the American colonists would sooner "shelter under the wings of the Royal Prerogative," exercised by "a Prince ... who must reasonably regard with an equal Eye the Happiness and Welfare of all his Dominions," than submit to the "unwarrantable Power of ... Parliament” ([Hicks] 1766, 21). 
some patriot pamphlets later) ambiguous and even contradictory when describing the constitutional relationship between the colonies, Parliament, and the crown. ${ }^{12}$ The back and forth of the pamphlet wars would sharpen their arguments, but this indicates that forensic requirements mounted alongside the demand of countering the claims of loyalist opponents, not that forensic requirements shaped the original formulation. Still less can these relatively early utterances support the case, as Nelson argues, that the "constitutional positions taken by the patriot writers . . . were primarily the products of debate" (Nelson 2011, 536). Something similar can be said regarding the famous appeal to George III from the Second Continental Congress, asking that he assert the prerogative on the colonists' behalf. According to John Philip Reid, this was the patriots' "last constitutional resort": "Once the Coercive Acts made it impossible . . to continue their strategy of avoiding the issue of Parliament's right to legislate," American Whigs, unwilling to depend on natural rights, turned to the "principles of the seventeenth century constitution, that is, to the royal prerogative" (Reid 1993, 155-56). But the fact that options may have narrowed to one does not harbor a need for such an extended backward reach.

Indeed, appeal to the royal prerogative was a well-oiled colonial ritual. In 1764, when rumors of an impending Stamp Act first reached the colonies, the Virginia Council and House of Burgesses implored the king "to protect [his] People . . . in the enjoyment of their ancient and inestimable Right of being governed by such Law regarding their internal Polity and Taxation as are derived from their own Consent" — qualified only by the proviso "[with] the Approbation of their Sovereign" (Virginia House of Burgesses, "The Petition to the King"; Morgan, 1959, 14). Shortly after the act's passage, the author of the Constitutional Courant-likely William Goddard-urged his fellow colonists to "lay before his majesty a united representation of their grievances" in the hopes that appeals from "a large and respectable body of ... subjects" would "have great weight and influence in the royal councils" ("The Constitutional Courant"; Jensen 1967, 82). As if heeding his advice, the Stamp Act Congress of 1765 "humbly beseech[ed]" their king to consider "the Distresses of [his] faithful Subjects on this Continent . . . and to afford them such Relief, as in [his] Royal Wisdom their unhappy Circumstances shall be judged to require" (Stamp Act Congress, "The Petition to the King"; Morgan 1959, 63-65). The same body petitioned Parliament to urge repeal of the Stamp Act, but the lukewarm promise to afford Parliament "all due

12. Nor is it our intent to deny that some prominent writers of the Stamp Act period, including Daniel Dulany (1765) and James Otis (1764), explicitly rejected the dominion theory of empire. 
subordination" consistent with the "English Constitution" stands in stark contrast with the unqualified pledges of "duty" and "allegiance" to the crown (Stamp Act Congress, "The Petition to the House of Commons"; Morgan 1959, 67. $)^{13}$

For Nelson, the important point to note is that the patriot reliance on the prerogative came increasingly to reference Stuart-era authorities. The Stuart monarchs had viewed the North American colonies as foreign dominions that were never annexed to the realm, exclusive dominions of the king that could be governed solely by prerogative. Stuart-era debates over control of the colonies were therefore inseparable from the larger struggle between king and Parliament for supremacy within the constitutional system, and the early Stuart monarchs vigorously resisted Parliament's attempts to intervene in colonial affairs. The patriot writers' frequent citations to these seventeenthcentury Parliamentary debates and their unabashedly taking the side of the hated Stuarts serves, in Nelson's reading, as evidence of their desperate position. With them now subject to a theoretically unlimited royal prerogative, the period of the pamphlet wars witnessed "an extraordinary revision of the patriot historical imagination," with those entering the constitutional debate fearing arbitrary power in all its forms, but particularly in the hands of the king, ending up as "zealous defenders of Stuart Royalism” (Nelson 2011, $537,542)$.

Upon closer inspection, however, the patriot defense of the prerogative relied far less on Stuart-era constitutional theory than it did on contemporary constitutional practice. Perhaps due to an awareness of the crown's being better situated for overseas management, or perhaps from sheer agenda overload, at the time the courts of Star Chamber and High Commission were abolished in 1641, supervision over the English plantations beyond the realm, including hearing judicial appeals arising from the Channel Islands of Guernsey and Jersey, was left under the authority of the king in Privy Council. As the empire expanded, so did the appeals to the jurisdiction of the Privy Council as court of last resort; no piece of evidence offered more conclusive proof that the Glorious Revolution had not fundamentally altered the colonies' posi-

13. As the Morgans pointed out in their study of the colonial reaction to the Stamp Act, the wording of the petition to the House of Commons was carefully crafted to avoid any suggestion that the delegates were endorsing the theory of Parliamentary sovereignty. Moreover, the Morgans note that some delegates objected to petitioning Parliament at all, for fear that that this would imply acceptance of Parliament's claims to sovereignty over colonial affairs $(1953 / 1995,114-17)$. It is also worth noting that the king received much of the credit for the act's repeal. Shortly after the news reached the colonies, the noted minister and pamphleteer John Joachim Zubly delivered a sermon that, while barely mentioning Parliament, repeatedly praised "our great and good King" for whom "it is a pleasure ... to repeal an act that gives pain unto his subjects" $(1766,5,18,20,23)$. 
tion within the constitutional system. ${ }^{14}$ After all, if the Glorious Revolution had destroyed all vestiges of prerogative power-including prerogative control of colonial affairs-why did the House of Lords not possess the authority to hear final appeals from the colonies, as it did from the courts in England? As Franklin wrote in the London Chronicle in 1768, it was "never . . . thought of . . . to make the House of Lords the ultimate resort in their appeals in law, ... the King in council remaining to this day the sole arbiter"; no single feature of colonial governance more "strongly mark[ed] the independence of the Americans of the British Parliament" (Franklin 1959, 15:23435). ${ }^{15}$ And here is James Wilson, in a pamphlet authored the same year, making a comparison with Ireland:

There are marks of the subordination of Ireland to Great Britain, which cannot be traced in the colonies. A writ of errour lies from the king's bench in Ireland, to the king's bench, and consequently to the house of lords, in England; by which means the former kingdom is subject to the control of the courts of justice of the latter kingdom. But a writ of errour does not lie in the king's bench, nor before the house of lords, in England, from the colonies of America. The proceedings in their courts of justice can be reviewed and controlled only on an appeal to the king in council. (Wilson 1774) ${ }^{16}$

The fact that some pamphlets from the early years of the constitutional crisis do, in fact, refer to Parliament as the "supreme legislator" of the empire may help to explain why scholars have so often mischaracterized the emergence of patriot royalism as a purely rhetorical maneuver. But upon close inspection, it is clear that most of these expressions of loyalty to Parliament, like that of the Stamp Act Congress, stop far short of endorsing the idea of sovereignty as a characteristic unique to Parliament. In fact, many of the writers who endorsed Parliament's role as supreme legislator saw nothing contra-

14. Although other colonies existed by 1640 , only the courts of the Channel Islands, which territory was a remnant of the older dominion of Normandy, were sufficiently developed institutionally to involve the Council in judicial appeals. Parliament, however, did not imagine these two courts to have once enjoyed the protection of common law and therefore did not consider them to be returned there by its actions restricting the king. See Smith (1950, 2-5, and chap. 1 passim).

15. Also see Franklin to Lord Kames, February 25, 1767 (Franklin 1959, 14:62-71, 68).

16. Wilson's essay, although written in 1768, was not published until 1774. John Adams and his Massachusetts colleagues made the same point in their famous 1773 exchange with Thomas Hutchinson (Adams 2000, 127). Significantly, even pamphleteers who were critical of this feature of the imperial system regularly cited it as evidence that the North American colonies had never been annexed to the realm (e.g., Bancroft, 1771, 63). 
dictory in declaring, in almost the same breath, that Parliament was guilty of meddling in matters that were the exclusive province of the crown. Thus Richard Bland, in his influential pamphlets of 1764 and 1766, conceded that Parliament was "without Doubt supreme within the Body of the Kingdom" and, as the "stronger power," capable of "forc[ing] any laws it shall think fit upon us" ("An Inquiry into the Rights of the British Colonies"; Jensen 1967, 118; "The Colonel Dismounted”; Bailyn 1965, 1:320). Yet Bland was equally emphatic in insisting that Parliament had no "constitutional right" to interfere in the "internal government" of the colonies, whose external oversight was relegated exclusively to the royal bureaucracy ("The Colonel Dismounted"; Bailyn 1965, 320). At no point in Bland's long struggle against the metropolitan authorities did he deny the king's "inherent power in the legislature" of the colonies, a power that was one of "the Prerogatives which [the king] has a Right to exercise without the Consent of Parliament" ("An Inquiry"; Jensen 1967, 118). A similar chain of reasoning can be found in the Connecticut legislature's pamphlet-length protest against the rumored Stamp Act, published in 1764 . Drafted primarily by the state's governor, Thomas Fitch, the pamphlet began by acknowledging Parliament's "general authority" and "supreme jurisdiction over all His Majesty's subjects" ("Reasons Why the British Colonies, in America, Should Not Be Charged with Internal Taxes"; Bailyn 1965, 387). Having conceded Parliament's “supreme jurisdiction," however, Fitch immediately made clear that his definition of "supreme" was narrow, not extending to the colonies' interior where the crown "governs . . . by and with the consent of the people represented in [their] Assemblies or legislative bodies" (Bailyn 1965, 390).

Going further, what the American defenders of prerogative power sought was not to vindicate the constitutional arguments of the Stuarts, but rather to preserve a constitutional structure that they had assumed to be permanentor at least not alterable without their consent-and which now seemed under deadly assault. Perhaps no pamphlet better illustrates this than John Joachim Zubly's influential An Humble Inquiry, published in 1769. Zubly's primary aim was to rebut the constitutional arguments of the 1766 Declaratory Act, which had asserted Parliament's "authority to make laws and statutes . . . to bind the colonies and people of America ... in all cases whatsoever" (6 George III, c. 12; The Statutes at Large 1767). Although he was prepared to concede Parliament a limited role in colonial affairs, Zubly insisted that the colonies were, from a constitutional standpoint, "only dependent on the crown." $\mathrm{He}$ thus resented the suggestion that the Declaratory Act had merely affirmed constitutional powers that Parliament had always possessed. Truth be told, Parliament was surreptitiously aiming at a transformation of the constitutional system - a fact that became evident when one considered the sheer num- 
ber of constitutional responsibilities that would potentially be transferred, under the terms of the Declaratory Act, from the king to Parliament. "Hitherto," Zubly noted, “all appeals from the colonies, after passing thro' chancery in America, have been made to the king in council"; but under the terms of the act, it seemed that Parliament might now claim for itself the power of deciding "future appeals." Similarly, although "the crown hath hitherto had a right of a negative upon all American laws," the constitutional logic of the Declaratory Act suggested that Parliament might well assert the power not only of "mak[ing] laws to bind the Americans," but also of "repeal[ing] laws made in America." And where the crown had always possessed the exclusive authority to "suspend . . . assemblies," Parliament had now begun to claim this power for itself, as witnessed by its recent decision to suspend the New York assembly over its refusal to implement the Quartering Act. In sum, Parliament seemed to have forgotten-or else to be willfully ignoring the fact-that each "branch" of the government had "its own distinct . . . and incommunicable prerogatives, rights or privileges," which were "assigned by the constitution." To permit Parliament to shift constitutional responsibilities from one branch to another was to grant Parliament a power which, in Zubly's view, it clearly did not possess-the power of "alter[ing] the constitution whenever it sees fit" $(1769,10-11)$.

The colonists were well aware that obligations of fidelity flowed both ways. Since the colonies would remain linked to the home country through the power of the crown, there need be no fear that exempting the colonies from parliamentary taxation would endanger the empire. Franklin made this point in his first riposte, and it was no empty concession: any colony that threatened the well-being of the empire could expect to be disciplined by the Privy Council through the same powers of hearing colonial appeals and reviewing colonial legislation. For this reason, Franklin concluded that the "dignity of the Crown was not concerned" in the Stamp Act controversy. If the Lords were offended by the colonists' hostile reception of the act, they had only themselves to blame for having “encroach[ed] on the Royal Power" (Franklin 1959, 13:219, 220, 214).

2

If the dramatic foil in the "patriot royalist" account is James I, in ours it is William III. In early 1696, just as Parliament was poised to vote on a reorganization plan for the governance of England's overseas colonies, authorities uncovered a Jacobite plot to assassinate the king. Expected to pass both houses, the plan would have transferred colonial affairs, since James I the jurisdiction of the king and Privy Council, to a new Council of Trade, with 
oversight of all matters touching on foreign and domestic commerce, its membership selected and compensated by Parliament. Diverted by the emergency, members of the legislature placed it on the table, from which it would never arise. ${ }^{17}$ Within weeks, the Privy Council, disquieted by what had seemed Parliament's immanent encroachment on the royal authority, announced its own version of reform.

Cognizant of the merchant community's dissatisfaction with the delays and maladministration of colonial business, the Privy Council's plan established a new inquisitorial body, nominated by itself and appointed by the king, composed of 16 members who would hear all complaints and make recommendations to the Council for final decision. This body, the Lords Committee on Trade and Plantations, known henceforth as the Board of Trade, within a short period of years expanded its jurisdiction to become the entry point for all appeals from colonial courts and chief advisor to the Council on the allowance or disallowance of colonial statutes. Although this structure would incur tinkering at the edges, and its assertiveness would wax and wane with the political winds, it would maintain its largely independent rule over the colonies until the American Revolution.

The prominence of the Privy Council's and the Board of Trade's activities in North America during the eighteenth century has not been a subject of debate. Our purpose in referencing them here, however, is to make a single claim, which is this: from 1696 onward they demonstrate sovereignty-operative, systematic, and unchallenged-with respect to American colonial affairs. Moreover, this sovereignty was one that colonial inhabitants could, without resort to outdated Stuart precedents, respectably embrace as legitimate authority against what they insisted were usurpations by Parliament. Nor is there any argument here concerning the role of these royal institutions in enforcing acts passed by Parliament, including the important Navigation and Staples Acts, and several other pieces of legislation before the Stamp Act in 1765; enforce they assuredly did, and on those occasions Parliament's own sovereignty was fully in evidence. Instead, our position is that the American colonists experienced lawmaking by Privy Council over which, in a practical sense, there was no higher authority. Institutionally, buckle shoes on the ground, this division of sovereignty was real and in place, all protests of Lord Mansfield and others as to its theoretical impossibility notwithstanding.

The nub of the matter, then, comes down to what is meant by sovereignty, which, as said earlier, we define as the making of new law-that is, the au-

17. The significance of this event is discussed in Smith $(1950,132-34)$. This book provides a fuller overview of the crown's governance of the colonies in the seventeenth and eighteenth centuries than any other we have found, and we rely heavily on it. 
thoritative and discretionary promulgation of novel or changed enforceable rules, including, on occasion, rules contrary to common law, and from which there is no existing provision for appeal. Of course, it would be difficult to exaggerate the sheer quantity of rule-making inherent in governing a faraway, geographically diverse, highly energetic population like that of North America. Any agency dedicated to resolving the myriad ambiguities incumbent upon such a vast array of affairs, its decisions in this case guided by a combination of charter provisions, governors' instructions, statutes, Orders in Council, and common law rights, would in the nature of the case be forced to exercise what might be deemed a kind of legislation in gross. Our interest, however, is limited to the laying down by the Privy Council and Board of Trade of nontrivial laws of general application, in a manner today more commonly associated with statute, across major areas of provincial activity.

This legislation occurred in two channels of activity. ${ }^{18}$ The first was in cases brought before the Council from the colonial courts as the venue of last appeal to the laws of England; with the passing of years, this increasingly entailed a hearing before a Committee of three Council members, in this respect continuing the Privy Council's ancient history as a criminal court. Most of this litigation concerned matters of personal significance, the largest category of cases involving assessments and penalties by customs officers; for our discussion, the important decisions are those where the Privy Council acted as positive lawmaker by filling in significant gaps of governance left by the absence of applicable English statutes or common law, or where there was significant doubt about the application of a given English law to the colonies. Consider, as an instance of the latter, bankruptcy legislation. The law of bankruptcy routinely pitted English merchants, factors, and lenders against overseas settlers and provincial traders, with wrangles in between among creditors, heirs, and assignees on either or both sides of the Atlantic. In England, bankruptcy proceedings were governed by a series of interlaced statutes reaching back to the time of Henry VIII and Elizabeth and proceeding into the 1760s. However, for many years it was uncertain whether North American debts were tied legally to any or all of this string.

In general, the principle covering the application of English law to the colonies, based loosely on a reading of Coke's opinion in Calvin's Case (Calvin's Case 7 Coke Report 1a 1608, 77 ER 377), was as follows: settlers do not (as

18. Although the interpretation is our own, we have taken our information on colonial legislation primarily from Russell (1915/2011) as well as Smith (1950). Also useful were Dickerson (1912), Andrews (1938, esp. chap. 9), and Washburne (1967). Where specific claims or interpretations are repeated, we have tried to footnote. Otherwise, colonial statutes or appeals in Privy Council where the references would be to archival materials are not given individual citation. 
an old rule would have it) carry English common law and statutes "on their backs" when they depart for their homes across the sea (Calvin's Case 7 Coke Report 1a 1608, 77 ER 377). Rather, the king grants his distant subjects the English law of inheritance, property, crimes, court procedure, and so on, in colonial charters and through instructions to governors, with the proviso that this law might be altered by the king or his local representatives at a later point, as long as the changes be consonant with English law. Parliament too had the power of alteration, but since colonies were not part of the British realm, the application of this authority overseas must be expressly stated in whatever statute it passed.

With regard to bankruptcy, under this principle, and based on legal interpretations in other legal contexts, it would have been expected that at least those parts of the bankruptcy law unchanged from the Tudor period would still have been valid in North America; this argument was heard frequently in bankruptcy suits. Throughout the eighteenth century, however, purely on the say-so of royal officers, English bankruptcy law was confined to the realm and not made available to debtors who accrued their obligations in the colonies. The first known promulgation of this nonavailability was contained in an opinion by the Solicitor General for the Board of Trade in 1723; this ignored the older statutes altogether. Another was in an opinion by Lord Mansfield, presiding over a Committee of the Council that heard an appeal from Virginia in 1762; Mansfield's opinion made no distinction between the older bankruptcy law and bankruptcy acts passed by Parliament after Virginia's settlement. These rulings were not limited to the particular facts or parties in dispute but were stated in categorical terms. Nor is there is any indication whether Lord Mansfield's Committee was influenced by a recent report from the Board of Trade that discussed how bankruptcy proceedings were disadvantageous to creditors living in England (Smith 1950, 492). ${ }^{19}$

A second example of conciliar legislation, this one in the absence of applicable English law, concerns the issuance of paper currency (for background, see Andrews 1938, 350ff.). A scarcity of specie relative to the volume of trade, consistently unfavorable trade balances, and the burdensome expenses connected with fighting Native Americans caused money and its valuation to be an unending preoccupation of colonial governments. In response, and over the protestations of worried English merchants, the Board of Trade in the earlier part of the eighteenth century permitted the colonies to issue paper currency, for which policy there was no precedent in the mother country. Although this issuance was subject to strict rules regarding quantity,

19. Lord Mansfield's opinion, found in the records of the Privy Council, is cited as Rickards et al. $v$. Hudson et al. 
duration, and refunding, the many change of hands inevitably involved in commercial transactions meant that these provisions could have only minimum effect. Finally, in 1751, following the surge in money printed during the Seven Years' War, Parliament passed an act providing that from now on colonies could no longer postpone the call-in date of existing bills or depreciate their value by fiat or reissue.

In reviewing an appeal from the New Jersey Supreme Court several years later, a Committee of the Privy Council issued the ruling that all debts contracted before 1751 were nonetheless subject to Parliament's act of that year. The litigation itself concerned a contract made in 1733, under which principal and interest were to be paid back in "good public bills of credit of the province or Massachusetts Bay, or current lawful money of New England.” Following the death of the original debtor, his executor tendered payment of the amount still due in the form of Connecticut and New Hampshire bills worth around $20 \%$ of the debt's original value. Although it was possible for the Committee to have treated the appeal as sounding in contract, under which law colonial practice would govern, it chose instead to announce new law, to be enforced in future cases. Moreover, in determining the actual value in sterling owed, Lord Mansfield, presiding, stated that because the debt had been so long outstanding, the general rule would be bent, requiring both parties to share evenly in the losses-an exceptional arrangement to highlight the rule's broader application. $^{20}$

A third and large field of conciliar legislation concerned rules for the daily operations of colonial governments. These ranged from the payment of salaries to royal customs officers and Anglican ministers, to the holding of elections, to rules about which colonial officer had the final say over naturalization of new residents. At a more systemic level were such matters as the relations of colonial and English courts in both their separate and interlocking functions. Some situations had no English analog. For instance, a question unique to the colonies was whether American common law courts might issue writs of prohibition to interrupt or preempt actions like seizures of vessels and forfeiture of goods that were ongoing in the local courts of vice-admiralty. In England, this problem had been settled under the Stuarts in favor of common law, by limiting Admiralty jurisdiction to the open seas and leaving the viceadmiralty courts, originally designed to adjudicate disputes on the inland waters, to wither away.

Until the end of the seventeenth century, England commissioned no viceadmiralty courts in the colonies. Settlement of marine disputes was handled 
under arrangements made by individual governors; these might be proceedings in the regular common law courts, special courts of oyer and terminer, or hearings before the governors' councils or other civil bodies; all of these included jury trial. In 1697, as part of its reorganization of colonial governance, the Privy Council drew up new vice-admiralty districts for the colonies and instructed governors to establish them and appoint their judges, who would decide the case without juries participating (when, in 1696, Parliament placed illicit trade touching the American colonies under Admiralty jurisdiction, it had assumed their imminent creation). Over the next decade, these courts' authority sans juries expanded to cover the standard maritime concerns-seamen's wages, seizures, prize cases, and so on-as well as violations of the revenue acts, which in England itself would have been heard by the equity court of Exchequer (Surrency 1967, 265-67).

Our interest here is not so much with the creation of these courts as with the rules the Council and Board of Trade provided to mitigate their persistent conflicts with the courts of common law. Beginning in 1720, based on an opinion written by the Board of Trade's counsel to the effect that a denial of the common law writ of prohibition would deny due process to persons too poor to appeal their case to the High Court of Admiralty, the Board and other Privy Council agencies repeatedly found in favor of the courts of common law. For instance, in response to the argument by the Collector of Customs of New York that the writs of prohibition would make the Navigation Acts unenforceable, a Committee of the Privy Council decided that the words "in any of his Majesty's Courts" specified by Parliament as the place for legalizing maritime seizures and forfeitures would henceforth include only courts of record, which Admiralty was not. ${ }^{21}$ True, this bias against Admiralty followed a pattern laid down in England during the previous century, but its source cannot be located in any institutional legacy or judicial precedent- the Privy Council was bound by neither; rather, the Council's act constituted independent legislation.

All of the appeals above involve statutes. Therefore, it will be instructive to point to legislation issued against the background of common law. Winthrop $v$. Lechmere (1727) is a much-analyzed dispute, mainly for its anticipation of judicial review, although, notably, no less a scholar than Edward Corwin wrote that, although in the setting of the Privy Council, the case was a "legislative" and not a judicial proceeding (Corwin 1910, 103). The decision is also known for being one of the rare instances when a colonial statute was declared illegal ab initio, that is, null and void from its beginning. In Lechmere,

21. See, on The Sloop Mary and Margaret, finally decided in 1741, as well as the relevant Admiralty cases generally, Smith (1950, 514-20). 
a Privy Council committee upheld the right of the plaintiff to the privileges of common-law primogeniture-the right of the oldest living male heir to inherit the entire estate of a deceased, which was also the rule in Englandagainst the Connecticut law and custom of dividing family legacies among the surviving wife and all living children. The ruling was on the grounds that any other system was repugnant to English law, which had been granted by the king in the colony's charter. What is most interesting for our purposes is a decision that followed shortly after Lechmere, in the case of Philips $v$. Savage, where an heir contested a Massachusetts inheritance law identical to the one recently turned aside in Lechmere. In this second case, the plaintiff rested his argument on the express disavowal in the original Massachusetts charter of all enactments "repugnant or contrary" to English law, something no longer stated in the newer charter of 1691 (Goebel 2010, 73ff.; Smith 1950, 537ff., 562ff.).

For reasons pertinent to our analysis, a Committee of the Privy Council supported the validity of the statute. Defenders of the statute pointed to the Council's formal approval of Massachusetts's inheritance law decades before; the other side, backing primogeniture, put it that past approval was of no avail, since even the king could not disobey English law or make an illegal instrument legal. The Council, on the other hand, saw things differently from both: nothing in the Massachusetts charter prevented the king, once he had granted English law to the colony, from subsequently making or allowing new law: Lechmere was not law in Massachusetts. With regard to this about-face, we might note that historically Privy Council courts-Chancery, Star Chamber, High Commission-had been more flexible and remedy oriented in their proceedings than the precedent-bound courts of common law. Still, the episode cannot be cordoned as a one-off remedy in a private lawsuit, for the ruling affected the entire colony of Massachusetts in the all but universal activities of making wills and inheriting property. The rules of inheritance in both colonies occurred in legislative acts. Connecticut was provided with new law, no further legislation required; the Privy Council's action in Philips gave necessary confirmation to the statute already on the books in Massachusetts.

This brings us to the second major channel of Privy Council legislation, which was its approval or disallowance of all statutes passed by colonial assemblies. The Council's usual standard for decision was conformity with English law and policy. It found law expressed in Parliamentary statutes, in common law, in the Orders of the King's Privy Council, and in colonial charters and instruction to governors. It conceived policy in largely commercial terms, but policy also embraced such general purposes as maintaining peace among provincial neighbors, fostering morality and religion, and preventing 
“unseemly infringements" on private rights (Russell 2011, 109). Conformity was expected and prescribed by the Privy Council from the early seventeenth century; after the Restoration, however, the requirement had been enforced in desultory fashion by a changing array of conciliar agencies. In 1696, under the reorganization of the Board of Trade, the process was regularized, with colonial governors instructed to transmit all colonial laws within three months of enactment, along with their recommendations and observations according to a prescribed formula and with duplicate copies sent by the next conveyance, upon a penalty of one year's salary in the event of disobedience. Once the statutes were received, the Board of Trade, after consulting with crown law officers, agents for the colonies, and other experts and interested parties like manufacturers, merchants, and bishops, made a recommendation as to their disposition to the Privy Council.

Earmarks of legislation will be obvious already in the focus on policy and in the regular consultation with parties outside royal precincts. Among the latter, moreover, were disgruntled persons who had filed petitions of complaint or requests for reconsideration of some statute that had lain undisturbed, without any action taken, perhaps for years; and Treasury officials, who were regularly consulted on all matters of revenue-only once was a bill, from the Virginia assembly, concerning the shipment of tobacco, allowed to "lie" over Treasury's recommendation that it be disallowed (Russell 2011, 73). Crucially, no colonial enactment was lawfully complete without the Council's approval; it remained in limbo, locally enforceable to be sure, but still subject to the king's eventual veto and even the reversal of actions consummated under its aegis. ${ }^{22}$ Statutes reviewed covered the entire legislative range. Duties on the importation of slaves were allowed. Imposts on foreign goods were permitted as long as they contained a suspending clause that postponed their effect until approved by the Council and they did no damage to British trade; after 1718, this excluded goods arriving on British vessels. Trade with the Indians on their borders was left to laws of individual colonial assemblies, so long as there was no injury to imperial interests. Harvard College was permitted a lottery. Debtor laws that disadvantaged British creditors were disal-

22. Although the role of Privy Council in colonial affairs has not received much attention from modern historians, this aspect of its activities has attracted interest as an arguable precursor of American judicial review. Although we draw no conclusions on that subject, we view the Board's statutory activity as legislative, and emphasize that aspect, placing it in a line of descent that includes the presidential veto. Those who emphasize the judicial coloration point out that a decision to "disallow" did not delegitimate transactions during the time intervening, resembling the situation of an American statute that remains in force prior to the Supreme Court declaring it unconstitutional, often several years later. See, e.g., Goebel (2010, 77-78). 
lowed, for instance, those that absolved debts of settlers in the frontier colonies; likewise, laws suspending statutes of limitations, lowering contractual interest rates, providing commissioners with excessive fees, laws that destroyed private property or interfered with legal instruments like wills-for instance, by requiring allocations for a beneficiary's education.

The reason the Privy Council gave for disallowance was most often some variety of nonconformity, with English law first of all, as already suggested, but not that only. Women's property acts, divorce laws, prohibitions of attachment for debt were struck as contrary to common law. Laws forbidding persons from living alone were "against family government." Provisions against the taking of fish from rivers was said to violate "fundamental rights of Englishmen"; the same for laws that discriminated against Quakers. Some statutes were disallowed because they were regarded as trivial: for instance, a statute naming the days of the week; or irrational, as imposing on those bearing false witness the penalty proposed for the person on trial; or too severe: for instance, in Massachusetts, a death penalty for "gathering sticks" on the Sabbath. In some cases the disallowance was for poor drafting, as covering more than a single topic or being imprecise, as when criminal statutes condemned "devilish practices." Some statutes strayed into the territory of the judiciary, like those providing divorces or levying fines on named individuals. Laws that imposed liabilities on royal officers were forbidden; colonial statutes might not exclude them from seats in the assembly. Diverse encroachments on the royal prerogative were disallowed: a grant for the exclusive manufacture of potash-this must be by letters patent; lunatics' lands given to overseers for custody-in England these lands reverted to the king. In some cases, there was a change of mind. Lotteries were permitted until 1760, when it was decided that they "encouraged dissipation."

A total of 8,563 laws were submitted to the Board of Trade for Privy Council approval. Of these, 469 , or $5.5 \%$, were disallowed. The percentage varied greatly by state: for Pennsylvania it was $15.5 \%$, for Massachusetts $2.8 \%$ (Russell 2011, 221). These limited data can say nothing about the intensity of feeling surrounding individual statutes or their objective importance to the colony's welfare. But they tentatively shift the burden of proof in favor of those who saw this regime as a viable and palatable one, if not ideally satisfying from the viewpoint of American self-government. Informal practices further supported such a benign position. Petitions to the Council or Board were almost always heard, and time limits were administered leniently. Rights to appeal were respected; appeals were allowed even if not provided in charters or sanctioned by local tribunals; all judgments were postponed until after appeals were heard. In conflicts between Orders in Council and enactments of assemblies, the latter prevailed unless they had been formally disallowed. 
Once decisions were announced, protests from the colonies were rare (Schlesinger 1913, 449-50).

But if it is agreed that the preceding account is all about legislation, is it also all about "sovereignty"? Could residents of the American colonies of adult age in the 1760 s, for instance, have taken sovereignty for granted as such? By our operative definition, the record supports an affirmative answer. There is no record of colonials appealing to Parliament over the head of the Privy Council, either on litigation or on local laws disapproved. More to the point, perhaps, what is striking is that setting aside complaints relayed about colonial delays and malfeasance made by constituents, there was no disagreement sufficiently intense between the Parliament and the Privy Council concerning the decisions and policies of the latter to have made a significant mark on this history. And whereas it is certainly possible that Parliament might have imposed its will, for whatever undetermined reason-lack of resources, absence of competing goals, inattention, co-optation by Council members sitting in its own chambers-Parliament did not.

Not a single act of Parliament passed during this long period undercut Privy Council colonial decisions; indeed, many seem to have been drafted around tables in Whitehall (Andrews 1938, 297). When Parliament intervened on vexed subjects it was uniformly at the request of the crown or the Board of Trade. It did so in 1731, for instance, when, in answer to a merchant's petition to the Privy Council, it passed a bill permitting merchants to recover debts through affidavits; in 1740 it authorized the naturalization of foreign Protestants after the Board registered its doubts as to the propriety of colonial laws to that end; in 1764, when, after repeated difficulty in the enforcement of the 1751 Act to protect currency valuation discussed above, it prohibited the printing of paper currency altogether. Sometimes it acted the "bad cop," as in 1715, when the colonies finally gave way to the Board's long imprecations for legislation creating a permanent civil list for support of local royal officers after Parliament announced that it would be taking matters into its own hands. Conversely, the Privy Council was respectful of legislation by Parliament. In 1703, the crown issued a proclamation fixing the value of specie but continued to tolerate the colonies' own rates; after Parliament fixed rates anew in 1708, the Council disallowed all such colonial acts; mindful of Parliament's legislation for transporting convicts to the colonies, it closely monitored taxes on their entrance, compensating with taxes on entering slaves.

In short: waving aside contemporaneous objections by partisans of Parliament that such a thing was a contradiction in terms, it is difficult to imagine how sovereignty shared by the royal establishment and Parliament would have looked dramatically different to Americans in the 1760s from the record we describe, with the former's sovereignty much more immediate. 
For decades now, scholars of American political thought have routinely contrasted the political thought of the Constitution's framers with the "republicanism" of the early revolutionary period (e.g., Wood 1969). Where the revolutionaries of 1776 had set out to curb "magisterial" or discretionary power in all its guises, the delegates to the Philadelphia Convention restored a significant degree of power to the executive while also shifting authority from the states to the national government. Thus, Sheldon Wolin writes that "the Founding Fathers were revolutionaries twice over: in 1776 they led an armed rebellion against the British Crown," while in 1787 they led "a political rebellion" against the constitutional principles of localism and democratic accountability "under which the colonists had fought the revolution" (Wolin 1990, 82-99, 91). In the limited space that remains, we will provide evidence that the depiction of the Constitutional Convention as a critical ideological turning point has been exaggerated. Indeed, we believe it is possible to discern, beneath the republican rhetoric of 1776 and the pointed exchanges of the founding period, a steady undercurrent of conciliar thinking. ${ }^{23}$

Consider, first, the revolutionary state constitutions, often cited to show that Americans by 1776 had ended their flirtation with Stuart-era constitutional theory in favor of a full-on embrace of republicanism. The point regularly noted about these early constitutions is the weakness of their chief magistrates - a feature said to suggest the former colonists' reflexive dislike of prerogative power. ${ }^{24}$ But if one looks more circumspectly at the substantive provisions of the early state constitutions, evidence of institutional continuity abounds; indeed, one discovers a variety of ad hoc councils and courts whose organization and procedures bear an uncanny resemblance to imperial practice. The most obvious example is, of course, the "privy councils" or "councils of state" that featured prominently in almost every constitution drafted during the revolutionary period. These councils were, to be sure, mere shadows of the original; they played no direct role in the lawmaking process, and they were intended, at least in part, as checks against the potentially arbitrary will of the governor. Still, the scope of their responsibilities is striking. In many states, privy council approval was mandatory for activities ranging from official appointments, to pardons, to calling up the militia. More to the point, these bodies exhibited the same changing memberships, flexible

23. Conciliar thinking by the judiciary in the early republic is a theme in Orren and Walker (2013).

24. Under the early revolutionary constitutions, governors were often selected by the legislature, saddled with an executive council of some sort, and deprived of a veto or "negative" over legislation. See, e.g., Wood (1969, 125-256). 
procedures, and blurring of functions that had characterized the English Privy Council and imperial governance generally.

In South Carolina, for example, the lieutenant governor and a majority of the eight-member privy council-whose members were drawn from the state legislature-were authorized to exercise all "the powers of a court of chancery" (South Carolina Constitution 1778, art. 24). ${ }^{25}$ In other states, the traditional conciliar function of serving as final judicial authority was vested outside the privy council in an ad hoc court or other body consisting of the governor and some number of high-ranking legislative or judicial officers. Thus, New Jersey's constitution of 1776 authorized the governor and any seven members of the upper house to sit as a court of "last resort" with the authority to issue pardons and hear appeals from lower courts (New Jersey Constitution 1776, art. 8). In Delaware, a "court of appeals" consisting of the chief executive and seven individuals appointed by the legislature was authorized to assume "all the authority and powers heretofore given by law in the last resort to the King in council, under the old government" (Delaware Constitution 1776, art. 17).

If the state-level privy councils were denied a direct role in the lawmaking process, the same cannot be said of another state-level institution likewise clearly modeled its imperial predecessor: the council of revision. The idea of vesting a council with the authority to review legislation received its fullest expression in New York, where the state's 1777 constitution created a Council of Revision-composed of the governor, the chancellor, and the judges of the supreme court (any three of which, including the governor, constituted a quorum)-with the power to veto legislation deemed "inconsistent with the spirit of [the] Constitution, or with the public good" (New York Constitution 1777, art. 3). Unlike the original Privy Council, the Council of Revision possessed only a conditional negative over legislation, as bills returned to the legislature could become law with the support of two-thirds of both chambers. But the Council was no parchment barrier either. In its first decade it vetoed no less than 58 bills, the vast majority for reasons of public policy or alleged violations of natural right; examples of the latter included laws that restricted the voting rights of free blacks and that delegated lawmaking power to administrative agencies. In addition, the Council took upon itself the Privy Council-like task of blocking measures deemed repugnant to national treaties or the Articles of Confederation (Roedel 1988, 267). These aspects of Council procedure have led at least one scholar to conclude that the constitution of

25. One study that makes note of the "fluid" nature of the "borderlines" between executive, judicial, and legislative authority in the early state constitutions is Adams (1980, 267). 
1777 simply imported imperial procedures "from Whitehall to New York" (Hulsebosch 2005, 176).

Although New York is sometimes dismissed as a lone wolf from a republican pack, institutions resembling the Council of Revision are found in even the most "republican" of the state constitutions. Thus, Pennsylvania's 1776 constitution, commonly described as "the most radical of all the new constitutions," featured a Council of Censors whose principal task was to periodically review the actions of the legislative and executive branches to ensure that the constitution was "preserved inviolate in every part." ${ }^{26}$ A watereddown version of the Council of Revision, to be sure, the Council of Censors possessed only the power to "recommend" that legislation repugnant to the state constitution be repealed. And yet the Censors did not lack for legal authority: they were empowered to subpoena persons, papers, and records; to pass public censures; to initiate impeachment proceedings; and even to call a constitutional convention (Pennsylvania Constitution 1776, sec. 47). A similar admixture of republican rhetoric and imperial form will be found in Thomas Jefferson's draft constitution for the state of Virginia. A determined foe of magisterial authority, Jefferson barred his state's chief magistrate from exercising any powers formerly claimed "by the crown as . . its prerogative." At the same time, however, he designed a council of revision composed of the governor, two councilors of state, and judges from the courts of chancery, common law, and admiralty, with the power to veto legislation for reasons of unconstitutionality or policy (Jefferson 1904-5, 4:155, 162). ${ }^{27}$

These institutional features of early state governance suggest that the delegates to the Philadelphia Convention did not have to look to the Stuarts for inspiration. ${ }^{28}$ Still, one may wonder how all this can be squared with the frequently noted unfavorable references to British institutions at the Convention and during the ratification debate. ${ }^{29}$ The answer, we believe, is that these expressions of distaste are often more accurately described as condemning the

26. On the "radical" nature of Pennsylvania's constitution, see, e.g., Williams (1988, 25$48)$, and Wood $(1992,915)$.

27. This tension within Jefferson's political thought is discussed at length in Bailey (2007).

28. The Confederation Congress likewise consciously claimed for itself many of the prerogative powers formerly exercised by the crown, as scholars including Jerrilyn Greene Marston (1987) and Peter Onuf $(1983,16)$ have pointed out.

29. Thus, LaCroix $(2010,154)$ writes that the defeat of Madison's proposal for a federal negative over state legislation may well be explained by "the rhetoric that Madison employed" in the Convention-in particular, his misguided decision to ask the delegates "to put themselves back in the place of colonists seeking the approval of their imperial masters." In a similar vein, Rakove (1997, 63-64) notes that Hamilton's "unrepublican" reference to the British monarchy as the model for a properly constructed executive "surely provoked reactions ranging from outrage to bemusement." 
“corrupted" institutional arrangements of the late 1760s. Take, for example, the debate over whether to include a privy council in the executive branch of the new national government. This debate is typically described as centering on the question of how best to restrain the potentially arbitrary will of the chief magistrate; and some of the delegates did in fact argue for an executive council on the grounds that "unity" in the executive branch would pave the way for an American monarchy. ${ }^{30}$ But in fact, what the delegates disliked about the English monarchy was not so much the unbounded authority of the office as the fact that the office had become so infested with place mongering as to be almost incapable of exercising its most important constitutional functions. After all, that the king had failed to come to the rescue of his American subjects was due at least in part, the delegates believed, to the influence of malevolent ministers and to the fact that the royal negative had lapsed into obsolescence. The very same delegates who employed the word "monarchy" as a term of derision also insisted that the American executive possess necessary "weight," "vigor," and "firmness." In short, the ideological antipode of "monarchy" was not a weak executive, but rather one strong enough to defeat the inevitable machinations of its political environment. ${ }^{31}$

A similar point can be made with respect to the debate over the precise form the executive veto should take in the new regime. Madison's original proposal, introduced to the Convention as part of the Virginia plan, was modeled on New York's Council of Revision; it included a council composed of the President and "a sufficient number of the National Judiciary" and having a conditional veto over "every act of the National Legislature" (Farrand 1966, 1:21). Significantly, there was little debate about the underlying principle of Madison's proposal; virtually all of the delegates agreed on the need for a robust "negative" to be lodged somewhere in the executive branch. Instead, debate centered on the question of whether a single executive or a multimember council would be more likely to stand up against the legislative branch. Thus, some delegates, including Madison and James Wilson, argued that only a council composed of the executive plus members of the judiciary would do (Farrand 1966, 2:74). Others reached exactly the opposite conclu-

30. See, e.g., Edmund Randolph's speech of June 1, in Farrand (1966, 1:66).

31. For example, Elbridge Gerry, the delegate who originally moved to "annex" a council to the executive, did so on the grounds that the presence of a council would "give weight" to the office. Similarly, Edmund Randolph, who denounced the idea of a single executive as the "foetus of monarchy," argued in the very same speech that the executive branch would be more capable of "supporting its own independence" if aided by a council. Also see Benjamin Franklin's lengthy speech on the ways in which George III's unscrupulous ministers had conspired to effectively erase the king's negative from the English constitution (Farrand 1966, $1: 66,99)$. 
sion: the inclusion of judges on the council would blur the line between executive and judicial functions, leaving the executive to be "seduced by the sophistry of the judges" (Farrand 1966, 1:139). ${ }^{32}$ In the end, of course, the delegates abandoned Madison's Council of Revision proposal in favor of a conditional veto lodged in the executive alone. This move sparked considerable criticism during the ratification debate, but not, typically, because AntiFederalists were concerned that the executive would abuse this formidable discretionary power. Rather, leading Anti-Federalists ironically echoed Madison and Wilson in expressing fear that a single executive, armed with only a conditional veto, would be too weak to resist the legislature. ${ }^{33}$

Nowhere, however, is the influence of royal institutions more evident than in the debate over the allocation of authority between the states and the new central government. It is well known that colonial arrangements influenced Madison's thinking on this question. ${ }^{34}$ But the point bears repeating: in the spring of 1787 , the principal architect of the Constitution wrote to both Edmund Randolph and George Washington to argue for a reformulated constitutional order that would closely track the structure of the British empire. Madison's primary complaint with respect to the existing structure of the Confederation was that the national government lacked power to discipline recalcitrant states and that, as a result, states were bickering among themselves, invading the rightful sphere of the national government, and trampling upon the rights of their own citizens. In order to remedy this situation, Madison argued, it would be necessary both to augment the formal powers of the national government and to arm that government with a Privy Council-style negative over state laws that were deemed repugnant to the common good. Every "positive power that can be given on paper" to the national government would be "unavailing," he concluded, until it was granted "a negative in all cases whatsoever on the legislative acts of the States . . a as was heretofore

32. The quotation is from Elbridge Gerry's speech of June 6 .

33. Given that George III, reigning for life and armed with an unqualified negative, had proven incapable of halting the creeping influence of Parliament, "Centinel" deemed it unlikely that the American executive "limited as he is in power," would "have the firmness or inclination" to impede the will of the Congress (Jensen 1976, 13:464; emphasis in the original). The Federal Farmer similarly argued for the inclusion of a Council of Revision on the grounds that it would it bolster the power of the executive vis-à-vis Congress-a claim he supported by comparing the operation of New York's constitution, which contained a Council of Revision, to that of Massachusetts, which featured only an executive veto (Storing 1981, 2:314). As Jack Rakove has pointed out, a common Anti-Federalist fear was that the executive was too "dependent" on the Senate, particularly in the areas of foreign policy and appointments, and that this feature of the Constitution would produce a Senatedominated regime $(1997,269-75)$.

34. The influence of the imperial model on Madison's constitutional thought is discussed in Zuckert (2009), LaCroix (2010, 145-7), Banning (1995, 126-27). 
exercised by the Kingly prerogative" (Madison 1962, 9:383, 370). The specific mechanism proposed by Madison-namely, ex ante review of state laws by the national legislature and the Council of Revision-was rejected, largely because many of the delegates thought it impractical. ${ }^{35}$ But while it is true that Gouverneur Morris expressed concern that Madison's version of the federal negative would "disgust all the states," it is also the case that neither he nor any other delegate disputed the claim that the central problem of imperial governance was also the central problem confronting the Convention: in short, somewhere there must exist a mechanism for "maintaining the harmony \& subordination" of the states, an instrument to "stifle in the birth every Act of every part tending to discord or encroachment." 36 The solution eventually arrived at was to replace Madison's proposal with the combination of the Supremacy Clause and judicial review-a solution that, as Mary Sarah Bilder has written, embodied the same "repugnancy principle" that had guided Privy Council review of colonial legislation, but now with the phrase "this Constitution, and the Law of the United States" substituted for the phrase " the laws of England" (2008, 215-40; also McLaughlin 1918). Under the new ordering, the Constitution and laws made under its authority would have the effect of repealing state law in the event of a conflict, and the judiciary would be tasked with the responsibility of determining whether particular laws were, in fact, adverse to the Constitution or to federal law. ${ }^{37}$

Although the defeat of Madison's version of the "federal negative" has been interpreted as a rejection of imperial procedures, there is little reason to believe that the delegates themselves saw it in this light. ${ }^{38}$ The Constitution's

35. Much of the debate centered on the question of whether it would be possible to exempt "local" or "police" legislation from the federal negative. An incredulous George Mason asked whether it was really Madison's intent that "no road nor bridge" would be built "without the sanction of the General Legislature" (Farrand 1966, 2:390).

36. The quotation is from Madison's speech of July 17 (Farrand 1966, 2:28).

37. As Morris told the Convention in a speech opposing Madison's version of the federal negative, "a law that ought to be negatived will be set aside in the Judiciary departmt. and if that security should fail; may be repealed by a Nationl. Law" (Farrand 1966, 2:28). For a thorough discussion of the delegates' reasoning on this point, see LaCroix $(2010,150$ 66).

38. LaCroix, e.g., contrasts the framers' "judicial" solution to the problem of repugnancy with the "structural" or "mechanical" procedure of Privy Council review. Over time, she argues, the framers' "judicial mode of organizing federalism" ensured that the concept of "jurisdiction"-rather than "sovereignty" — would become "the central organizing principle" of American federalism (2010, 165, 178-79). We agree with LaCroix's claim that the framers' design set in motion a process whereby the judiciary would eventually become the primary "locus of debates over both the practical and the ideological meaning of federalism." But as we argue above, there is little reason to believe that the delegates themselves believed that they had engineered a fundamental departure from the imperial arrangement. 
most ardent supporters consistently described the new federal system in precisely the same language that they had earlier used to describe the relation between the colonies and the metropole. Federalist writers offered assurances that although the new national government would be the supreme constitutional power, it would not as a matter of course interfere in "internal" state matters but would perform the necessary function of "adjusting," "harmonizing," or "assimilating" the disparate interests of the states. Considering that the adjectives most often employed in the Federalist Papers to describe the nationalgovernment—“judicious," "wise," "fair," "moderate," "equitable," and "just"-were the same terms used by patriot writers to describe the king's role as imperial arbiter, it seems fair to deduce that the language of "dominion theory" provided Federalist writers with the vocabulary they needed to legitimize and demystify the Convention's handiwork.

In some cases, the parallels between revolutionary-era descriptions of the imperial constitution and Federalist descriptions of the US Constitution are so striking that it is difficult to determine whether a given text is describing the King-in-Council or the new federal government. Writing in 1774, Hamilton drew the colonies' relationship to the mother country as one in which a number of "individual societies" were "conjoin[ed]" into "one common body politic" by the "central force" of a king who "mediated" disputes and prevented the "several parts of the empire" from pursuing their own interests at the expense of the "common good" (Hamilton 2008, 65). Fourteen years later it was the new federal government that would act as a "superintending authority," maintaining "harmony" between the states and ensuring that these "inferior orbs" did not "fly off from the common center" or otherwise undermine the "common interest" of the whole (Federalist no. 80, and Federalist no. 15; Wills 1982, 405, 73). To the extent that even leading AntiFederalists agreed on the need for a more robust "supreme federal head" to "direct" and "control" the 13 "consolidated republics," such language was well calculated to assuage fears of a national power grab ("Brutus," "No. I," and "Federal Farmer," "No. I"; Ketchum 2003, 271, 257).

In the end, the Federalists' arguments-or perhaps their machinationscarried the day. But it is a mistake, in our view, to characterize the Federalist triumph as a signal departure from the political thought of the previous decade, or from the previous century. The institutional innovations for which they are typically remembered-from the "energetic" executive, to the federal system, to the nascent power of judicial review-all had their roots in imperial rule. Once this is recognized, it becomes possible to perceive broad continuities in early American political thought that otherwise escape detection. At the same time, ideological dichotomies that once seemed self-evident become less distinct, or they disappear altogether. 
4

In his essay, "John Locke, the Great Recoinage, and the Board of Trade, 1695-1698," Peter Laslett remarks on the "striking paradox" that the codifier of the doctrines of self-government and trust "would himself have been a member of the body that became a historical symbol of the determination to deny these doctrines in the case of America and everywhere else." Laslett refers here to Locke's membership on the Board of Trade, a position he occupied between 1696 and 1700. As he notes, Locke's active involvement in imperial administration-he had earlier served as secretary to the same body in its previous incarnation as the Council on Trade and Foreign Plantations-helps to explain his surprisingly expansive conception of prerogative power, as well as his denial of Parliament's authority in the area of "federative" or external relations. Locke's assertion that "a good Prince .. . cannot have too much Prerogative" would seem to sit uneasily beside his description of arbitrary power as "slavery" and "tyranny," but only until one recalls his personal familiarity with the challenges entailed in administering a rapidly expanding empire and his determination that Parliament not interfere in the Board's activities (Locke 2003, 173; Laslett 1957, 371, 396). Laslett reminds us that Locke's political theory, although not simply derivative of contemporary policy concerns or institutional conflicts, was never far removed from them either.

That Locke, like his American admirers, could simultaneously advocate the principle of self-government and favor a broad prerogative further underscores the abiding association between ideas and institutions. Nothing we have said is meant to suggest that political actors or philosophers are incapable of thinking beyond the confines of their institutional settings. Our claim is not that the colonists were forced by their history to endorse the crown's prerogative in imperial affairs, nor is it to disclaim institutional backing for the opposite camp of parliamentary sovereignty. Rather it is that the course of political thought is rarely, if ever, completely decoupled from the trajectory of governmental institutions; this linkage, moving through time, is what students of American political development call "intercurrence" (Orren and Skowronek 2004). Political thought being what it is, minds are free to dwell on what seems politic or true, about or against the institutional world in which they must exist.

\section{REFERENCES}

Adams, John. 2000. The Revolutionary Writings of John Adams. Ed. C. Bradley Thompson. Indianapolis: Liberty Fund. 
Adams, Willi Paul. 1980. The First American Constitutions: Republican Ideology and the Making of State Constitutions in the Revolutionary Era. Chapel Hill: University of North Carolina Press.

Andrews, Charles M. 1938. The Colonial Period in American History. Vol. 4, England's Commercial and Colonial Policy. New Haven, CT: Yale University Press.

Bailey, Jeremy D. 2007. Thomas Jefferson and Executive Power. New York: Cambridge University Press.

Bailyn, Bernard, ed. 1965. Pamphlets of the American Revolution, 1750-1776. Vol. 1. Cambridge, MA: Belknap.

- 1967. The Ideological Origins of the American Revolution. Cambridge, MA: Belknap.

Bancroft, Edward. 1771. Remarks on the Review of the Controversy between Great Britain and her Colonies. New London, CT.

Banning, Lance. 1995. The Sacred Fire of Liberty: James Madison and the Founding of the Federal Republic. Ithaca, NY: Cornell University Press.

Bilder, Mary Sarah. 2008. The Transatlantic Constitution: Colonial Legal Culture and the Empire. Cambridge, MA: Harvard University Press.

$\rightarrow$ Black, Barbara. 1976. "The Constitution of Empire: The Case for the Colonists." University of Pennsylvania Law Review 124:1157-1211.

$\rightarrow$ Corwin, Edward S. 1910. "The Establishment of Judicial Review. I.” Michigan Law Review 9:102-25.

C.P. 1765. A letter to His Most Excellent Majesty, George the Third, King of GreatBritain, France, and Ireland, and Emperor of North-America (New York, 1765).

Dickerson, O. M. 1912. American Colonial Government, 1696-1765. Cleveland: Clark.

Dulany, Daniel. 1765. Considerations on the Propriety of Imposing Taxes in the British Colonies. Annapolis, MD: Jonas Green.

Farrand, Max, ed. 1966. The Records of the Federal Convention of 1787. 4 vols. New Haven, CT: Yale University Press.

Franklin, Benjamin. 1959-. The Papers of Benjamin Franklin. Ed. Leonard W. Larabee et al. 40 vols. New Haven, CT: Yale University Press.

$\rightarrow$ Goebel, Julius. 1930. Review of Parliament and the British Empire, by Robert L. Schuyler. Columbia Law Review 30:273-76.

-2010. Antecedents and Beginnings to 1801. Vol. 1 of History of the Supreme Court of the United States. Oliver Wendell Holmes Devise. New York: Cambridge University Press.

Greene, Jack P. 1986. Peripheries and Center: Constitutional Development in the Extended Polities of the British Empire and the United States, 1607-1788. New York: Norton.

- 2011. Constitutional Origins of the American Revolution. New York: Cambridge University Press.

Hamilton, Alexander. 2008. The Revolutionary Writings of Alexander Hamilton. Ed. Richard B. Vernier. Indianapolis: Liberty Fund.

[Hicks, William]. 1766. Considerations upon the Rights of the Colonists to the Privileges of British Subjects. New York.

Hulsebosch, Daniel J. 2005. Constituting Empire: New York and the Transformation of Constitutionalism in the Atlantic World. Chapel Hill: University of North Carolina Press. 
30 • American Political Thought • Spring 2014

$\rightarrow$ - 2011. "The Plural Prerogative." William and Mary Quarterly 68:583-87.

Hyneman, Charles S., and Donald S. Lutz, eds. 1983. American Political Writing during the Founding Era. 2 vols. Indianapolis: Liberty.

Jefferson, Thomas. 1904-5. Works of Thomas Jefferson. 12 vols. New York: Putnam's.

Jensen, Merrill, ed. 1967. Tracts of the American Revolution, 1763-1776. Indianapolis: Bobbs-Merrill.

- ed. 1976. The Documentary History of the Ratification of the Constitution. Madison: State Historical Society of Wisconsin.

Ketchum, Ralph, ed. 2003. The Anti-Federalist Papers and the Constitutional Convention Debates. New York: Signet Classics.

LaCroix, Alison L. 2010. The Ideological Origins of American Federalism. Cambridge, MA: Harvard University Press.

Laslett, Peter. 1957. "John Locke, the Great Recoinage, and the Origins of the Board of Trade, 1695-1698." William and Mary Quarterly, 3rd ser., 14:370-402.

Locke, John. 2003. Two Treatises of Government and a Letter concerning Toleration. Ed. Ian Shapiro. New Haven, CT: Yale University Press.

Madison, James. 1962-. The Papers of James Madison. Ed. William T. Hutchinson et al. Chicago: University of Chicago Press.

$\rightarrow$ Maier, Pauline. 2011. "Whigs against Whigs against Whigs: The Imperial Debates of 1765-76 Reconsidered." William and Mary Quarterly 68:578-82.

Martson, Jerrilyn Greene. 1987. King and Congress: The Transfer of Political Legitimacy, 1774-1776. Princeton, NJ: Princeton University Press.

McIlwain, Charles H. 1924. The American Revolution: A Constitutional Interpretation. New York: Macmillan.

$\rightarrow$ McLaughlin, Andrew C. 1918. "The Background of American Federalism.” American Political Science Review 12:215-40.

Morgan, Edmund S., ed. 1959. Prologue to Revolution, Sources and Documents on the Stamp Act Crisis, 1764-1766. Chapel Hill: University of North Carolina Press.

Morgan, Edmund S., and Helen M. Morgan. 1953/1995. The Stamp Act Crisis: Prologue to Revolution. Chapel Hill: University of North Carolina Press.

Nelson, Eric. 2011. "Patriot Royalism: The Stuart Monarchy in American Political Thought, 1769-75." William and Mary Quarterly 68:533-72.

Onuf, Peter. 1983. The Origins of the Federal Republic: Jurisdictional Controversies in the United States, 1775-1787. Philadelphia: University of Pennsylvania Press.

$\rightarrow$ Orren, Karen. 1994. "Labor Regulation and Constitutional Theory in the United States and England.” Political Theory 22:98-123.

Orren, Karen, and Stephen Skowronek. 2004. The Search for American Political Development. New York: Cambridge University Press.

$\rightarrow$ Orren, Karen, and Christopher Walker. 2013. "Cold Case File: Indictable Acts and Officer Accountability in Marbury v. Madison." American Political Science Review 107, no. 2 (May): 241-58.

Otis, James. 1764. Rights of the British Colonies Asserted and Proved. Boston: Edes \& Gill.

Rakove, Jack N. 1997. Original Meanings: Politics and Ideas in the Making of the Constitution. New York: Vintage.

Reid, John Phillip. 1993. Constitutional History of the American Revolution: The Authority of Law. Madison: University of Wisconsin Press. 
Roedel, Jeff. 1988. "Stoking the Doctrinal Furnace: Judicial Review and the New York Council of Revision.” New York History 69:261-83.

Russell, Elmer Beecher. 1915/2011. The Review of American Colonial Legislation by the King in Council. La Vergne, TN: Nabu Public Domain Reprints.

$\rightarrow$ Schlesinger, Arthur M. 1913. "Colonial Appeals to the Privy Council. II." Political Science Quarterly 28:433-50.

Schuyler, Robert Livingston. 1924. Parliament and the British Empire: Some Constitutional Controversies concerning Imperial Legislative Jurisdiction. New York: Columbia University Press.

Smith, Joseph H. 1950. Appeals to the Privy Council from the American Plantations. New York: Columbia University Press.

The Statutes at Large, ed. Danby Pickering (London, 1767), 27:19-20.

Storing, Herbert J., ed. 1981. The Complete Anti-Federalist. 7 vols. Chicago: University of Chicago Press.

$\rightarrow$ Surrency, Edwin C. 1967. "Courts in the American Colonies." American Journal of Legal History 11:253-76.

Washburne, George A. 1967. Imperial Control of the Administration of Justice in the Thirteen American Colonies, 1684-1776. New York: AMS.

$\rightarrow$ Williams, Robert F. 1988. "The Influences of Pennsylvania's 1776 Constitution on American Constitutionalism during the Founding Decade." Pennsylvania Magazine of History and Biography 112:25-48.

Wills, Garry, ed. 1982. The Federalist Papers. New York: Bantam.

Wilson, James. 1774. Considerations on the Nature and the Extent of the Legislative Authority of the British Parliament. Philadelphia: William \& Thomas Bradford.

Wolin, Sheldon. 1990. The Presence of the Past: Essays on the State and the Constitution. Baltimore: Johns Hopkins University Press.

Wood, Gordon S. 1969. The Creation of the American Republic, 1776-1787. Chapel Hill: University of North Carolina Press.

- 1992. "Foreword: State Constitution-Making in the American Revolution." Rutgers Law Journal 24:911-26.

. 2004. The Americanization of Benjamin Franklin. New York: Penguin.

$\rightarrow$ - 2011. "The Problem of Sovereignty.” William and Mary Quarterly 68:573-77.

Wright, Esmond. 1986. Franklin of Philadelphia. Cambridge, MA: Belknap.

Zubly, John Joachim. 1766. The Stamp-Act Repealed. Charleston, SC.

. 1769. An Humble Inquiry into the Nature of the Dependency of the American Colonies Upon the Parliament of Great-Britain. Charleston, SC.

Zuckert, Michael P. 2009. "Judicial Review and the Incomplete Constitution: A Madisonian Perspective on the Supreme Court and the Idea of Constitutionalism." In The Supreme Court and the Idea of Constitutionalism, ed. Steven Kautz et al. Philadelphia: University of Pennsylvania Press. 